\title{
Spatial Distribution of Soil Organic Carbon in Amazonia
}

\author{
G. F. Franco ${ }^{1}$, J. J. L. L. de $\operatorname{Souza}^{2}$, A. L. L. de Faria ${ }^{3}$, M. C. C. Campos ${ }^{4}$ \& L. M. Da Costa ${ }^{1}$ \\ ${ }^{1}$ Soil Science Departament, Univeridade Federal de Viçosa, Viçosa, Brazil \\ ${ }^{2}$ Geography Departament, Universidade Federal do Rio Grande do Norte, Caicó, Brazil \\ ${ }^{3}$ Geography Departament, Universidade Federal de Viçosa, Viçosa, Brazil \\ ${ }^{4}$ Instituto de Agricultura e Ambiente, Universidade Federal do Amazonas, Humaitá, Brazil \\ Correspondence: J. J. L. L. de Souza, Geography Departament, Universidade Federal do Rio Grande do Norte, \\ Joaquim Gregório St., 59.300-000, Caicó, Brazil. Tel: 55-84-9866-039-88. E-mail: jjlelis@gmail.com
}

Received: May 2, $2018 \quad$ Accepted: June 17, $2018 \quad$ Online Published: August 15, 2018

doi:10.5539/jas.v10n9p153 URL: https://doi.org/10.5539/jas.v10n9p153

\begin{abstract}
The Amazon rainforest is considered the most important ecosystem in the world for the global carbon balance due to its high carbon storage in soil and in the vegetation. Unfortunately, there are few studies about organic fraction of its soils. Thus, the present research aimed to quantify the soil organic carbon content (OC) and to analyze its spatial distribution using 701 soil samples from minimally anthropic areas compiled from previous studies. Descriptive statistics, Pearson correlation and spatial variability analyses of OC and other physical and chemical soil data were performed. The high variability of OC between soil groups were attributed to the preservation and protection of carbon by oxides, reduction process and organic-rich parent material. OC was strongly positively correlated with total nitrogen $(\mathrm{N})$ content, $\mathrm{C}: \mathrm{N}$ ratio and cation exchange capacity at $\mathrm{pH}$ 7.0. The maps produced showing the spatial distribution of $\mathrm{CO}$ and that based on $\mathrm{C}: \mathrm{N}$ ratio would be support for the creation of priority areas in the conservation of ecosystem.
\end{abstract}

Keywords: Amazon rainforest, carbon stock, deforestation, conservation of ecosystem

\section{Introduction}

About two-thirds of the terrestrial carbon is stored in the soil, with higher concentrations in upper layers (Jobbágy \& Jackson, 2000; Lal, 2004, 2005). Therefore, the knowledge of spatial variability of soil organic matter contents serves as support for creation of priority areas for conservation, maintenance of carbon stocks in soil and subsequent reduction of $\mathrm{CO}_{2}$ emission into the atmosphere.

The Amazon rainforest represents over half of the planet's remaining forests, and stocks large quantities of carbon in plant biomass (Asner et al., 2010; Nogueira et al., 2015) and in the soil (Batjes \& Dijkshoorn, 1999; Koele et al., 2017; Fearnside, 2018). Deforestation caused a reduction of total organic carbon of $16.7 \%$ in the Amazonia biome (11.2 Pg C) through 2013, excluding carbon loss from the effects of fragmentation, selective logging, fires, mortality induced by recent droughts and clearing of forest regrowth (Nogueira et al., 2015). Due to its high carbon stored in the soil, the Amazonian biome is considered one of the most important to maintain the global carbon balance (Houghton et al., 2009; Barros and Fearnside, 2016; Nobre et al., 2016).

The Brazilian Legal Amazon occupies approximately 6,000,000 $\mathrm{km}^{2}$ (59\% of Brazilian territory), where $24,000,000$ people live in ten states (IBGE, 2011). The Amazon rainforest is composed of several phytophysiognomies (IBGE, 2010). Seasonal floodplain forest (igarapé), dense ombrophile forest and submontane open ombrophile forest are phytophysiognomies of higher biomass production than white-sand vegetation (campinarana) and savannas (Brazilian cerrado) (J. Demattê \& J. Demattê, 1993; Puig, 2001; Aduan et al., 2003; Mendonça et al., 2017).

To have a good picture of the organic carbon stock in the soils of this biome, the study area chosen was the state of Amazonas, since much of its forest cover is preserved and has the largest territorial extension of the region (IBGE, 2010).

A wide range of biomass estimation, as well its correlation with soil properties and distribution, have indicated that variability of soil organic carbon was poorly known. Basically, the amount and quality of natural soil organic carbon is influenced by relief, vegetation type and land use (Houghton et al., 2001; Lima et al., 2005; 
EMBRAPA, 2007; Campos et al., 2011; IBGE, 2011). In fact, most studies do not consider on carbon stocks the inherent soil variability for allowing various rates of biomass production. Therefore, the objectives of the study were to: (i) determine the soil organic matter content of different soil classes and suborders of Amazonas State, (ii) measure its correlation with other soil properties and (iii) analyze its spatial variation.

\section{Material and Methods}

The State of Amazonas $\left(2^{\circ} 09^{\prime} \mathrm{N}\right.$ to $9^{\circ} 49^{\prime} \mathrm{S} ; 56^{\circ} 05^{\prime} \mathrm{W}$ to $73^{\circ} 49^{\prime} \mathrm{W}$ ) (Figure 1A), is the largest federative unit in Brazil $\left(1,559,159.148 \mathrm{~km}^{2}, 18 \%\right.$ of Brazilian territory) and has $98 \%$ of its primary vegetation cover preserved (Soares and Higuchi, 2006; IBGE, 2010, 2011). The precipitation of the state has an east-west gradient (1,700 $\mathrm{mm}^{-1}$ for values greater than $4,000 \mathrm{~mm}$ year ${ }^{-1}$ ), with an annual mean temperature above $18{ }^{\circ} \mathrm{C}$ (Marengo and Nobre, 2009). Amazonas state is partially covered by sedimentary rocks, distributed in the Tapajós, Amazonas and Solimões sedimentary basins. The Tapajós sedimentary basin has Silurian sandstones, quartz-sandstones and siltstones. Devonian-carboniferous siltstones and Cretaceous quartz-sandstones fill the Amazon sedimentary basin. The Solimões sedimentary basin has Pleistocene coquina, lignite and unconsolidated sediments and Miocene sandstones and conglomerates (Reis et al., 2006). Proterozoic acid igneous and metamorphic rocks are found in the Guianas shield in the north, and Central Brazil shield in the south (Figure 1B).

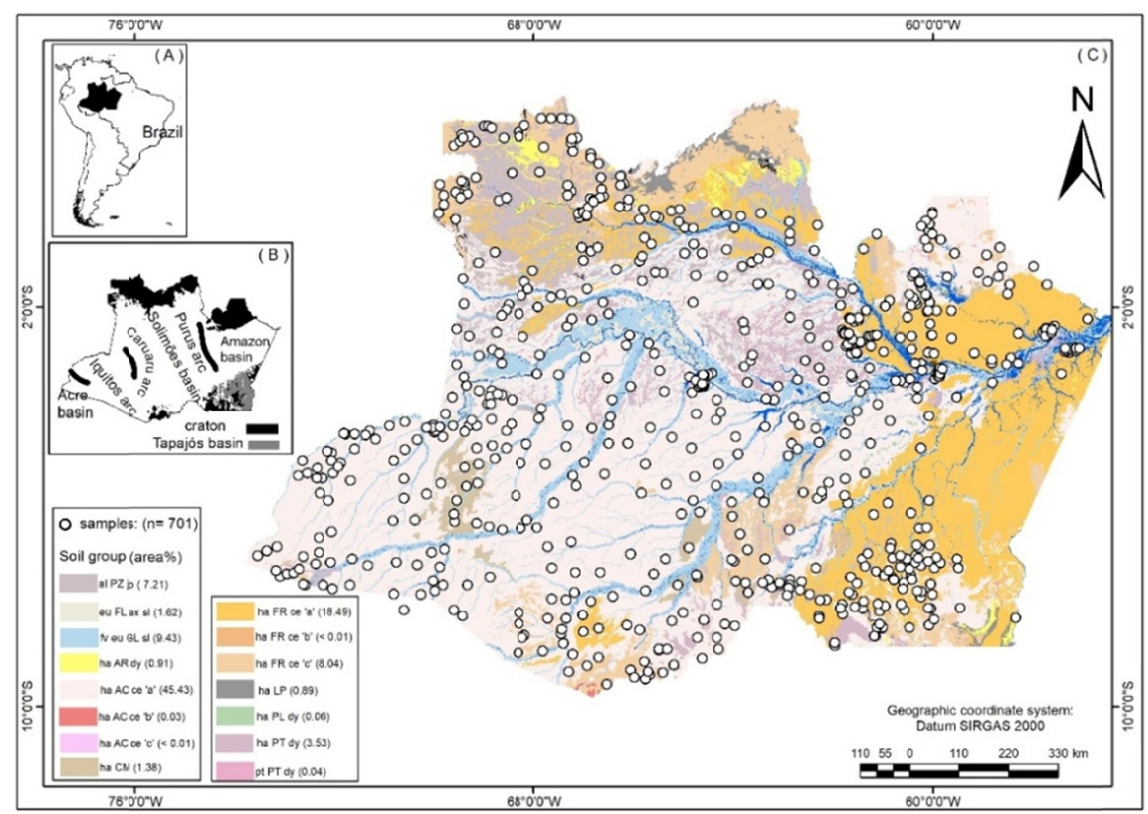

Figure 1. Location of study area (A). Geological provinces of Amazonas State (B). Samples collected according to soil group (C)

Note. al PZ jp= Alic Podzol Hyperspodic; eu FL ax sl= Eutric Fluvisol Alcalic Siltic; fv eu GL sl= Fluvic Eutric Gleysol Siltic; ha AR dy= Haplic Arenosol dystric; ha AC ce 'a'= Haplic 'Yellow' Acrisol clayic; ha AC ce 'b'= Haplic 'Red' Acrisol clayic; ha AC ce 'c'= Haplic 'Red-Yellow' Acrisol clayic; ha CM= Haplic Cambisol; ha FR ce 'a'= Haplic 'Yellow' Ferralsol clayic; ha FR ce 'b'= Haplic 'Red' Ferralsol clayic; ha FR ce 'c'= Haplic 'Red-Yellow' Ferralsol clayic; ha LP= Haplic Leptosol; ha PL dy= Haplic Planosol dystric; ha PT dy= Haplic Plinthosol dystric.

Deeply weathered soils represent approximately $79.22 \%$ of Amazonas State area (Acrisols, Ferralsols and Podzols) are dominant due to wet tropical climate (Figure 1C). On crystalline rocks occur Haplic Leptosol, 'Red' Haplic Ferralsol Clayic and 'Red-Yellow' Haplic Ferralsol Clayic and Alic Podzol Hyperspodic. In the sedimentary areas, 'Red-Yellow' Haplic Acrisol Clayic occur on the Miocene sediments of the Solimões Basin, 'Yellow' Haplic Acrisol Clayic, 'Yellow' Haplic Ferralsol Clayic, Petric Plinthosol and Haplic Plinthosols and Alic Podzol Hyperspodic on Pleistocene sediments of the Solimões Basin and on the Amazonas and Tapajós basins. 'Red' Haplic Acrisols occur in (Reis et al., 2006; CPRM, 2010; IBGE, 2015b).

The dense ombrophilous forest is the main phytophysiognomie of the state, covering $65 \%$ of the Amazonian rainforest, on Ferralsols, Acrisols and Plinthosols in residual non-flooding plateaus of Phanerozoic and 
Pleistocene sedimentary areas. The open ombrophylous forest occurs on Acrisols in lowlands of Miocene sedimentary areas. The white-sand vegetation, a savanna scleromorphic vegetation called "Campinarana", occurs on Podzols derived from Cenozoic unconsolidated sediments. The submontane open ombrophilous forest occurs on "Red" and "Red-Yellow" Ferralsols developed on plateaus raised in the crystalline shells. The constantly flooded areas are occupied by seasonal flooded alluvial forest (Igapós), on Fluvic Eutric Gleysol Siltic and Eutric Fluvisol Alcalic Siltic derived from Quaternary sediments (Marques et al., 2002; Reis et al., 2006).

Soil group, chronostratigraphic unit, lithology, rock type and analytical data of 701 georeferenced surface soil samples in the State of Amazonas were compiled (DNPM, 1975, 1976a, 1976b, 1976c, 1977a, 1977b, 1977c, 1978a, 1978b, 1978c, 1980) (Figure 1C). Samples were collected in minimally anthropized areas. The physical and chemical analyzes of the samples were performed according to the suggested methods for Brazilian soils (Donagema et al., 2011). The samples were air-dried and sieved using a $2 \mathrm{~mm}$-mesh diameter sieve. The physical and chemical properties of samples were determined according to procedures proposed by Claessen (1997) whereby sand, silt, and clay contents were determined by the sieve-pipette method. Exchangeable $\mathrm{Ca}, \mathrm{Mg}$, and $\mathrm{Al}$ contents were determined in $1 \mathrm{~mol} \mathrm{~L}^{-1} \mathrm{KCl}$ solution, while $\mathrm{K}^{+}$and $\mathrm{Na}^{+}$were determined in Mehlich-1 solution. Potential acidity $(\mathrm{H}+\mathrm{Al})$ was determined by titration in ammonium acetate buffered to $\mathrm{pH}$ 7.0. Cation exchange capacity (CEC) was calculated based on the data from the above chemical elements as follows: $\mathrm{Ca}^{2+}+\mathrm{Mg}^{2+}+$ $\mathrm{Na}^{+}+\mathrm{K}^{+}+(\mathrm{H}+\mathrm{Al})$. Organic carbon (OC) was determined by the oxidation of organic matter with potassium dichromate in sulfuric medium. Nitrogen was determined by Kjeldal method. Updates in soil classification followed the Brazilian Soil Classification System (Santos et al., 2013) and World Reference Base for Soil Resources (IUSS Working Group WRB, 2014).

Descriptive statistics were performed for all 701 samples and combined by soil class. Due to absence of normality, the high number of samples and the heterogeneity of OC contents, the data set was submitted to the non-parametric Kruskal-Wallis hypothesis test at 5\% probability using IBM SPSS Statistics 24.0 software (IBM, 2016). Correlations between organic carbon other soil physical and chemical properties were analysed.

Principal Component Analysis (PCA) was performed to elucidate the relationship between soil properties. Data were transformed into logarithmic scale and standardized to assume a normal distribution (Wackernagel, 2003; McKillup \& Dyar, 2010).

Spatial distribution of organic carbon and that of C:N ratio were interpolated to whole study area by ordinary kriging. Autocorrelation, anisotropy and tendency were fittted to semivariogram. Maps were performed using PASSaGe v.2 and ArcGIS 10.1 $1^{\circledR}$ (Rosenberg \& Anderson, 2011).

\section{Results}

Fluvisols and Gleysols presented the lowest OC contents $(1.16 \% \pm 81 \%$ and $1.68 \%$ and $\pm 107 \%)$ and C:N ratio values $(5 \pm 67 \%$ and $5 \pm 68 \%)$. On the other hand, Ferralsols, Acrisols, Planosols and Podzols presented the highest OM contents $(2.18 \%$, on average) and higher $\mathrm{C}: \mathrm{N}$ ratio $(14$, on average), in addition to high coefficient of variation values $(13 \pm 44 \%)$. Despite the differences between OC contents, there is no significant statistical difference between the mean OC contents of Ferralsols, Acrisols and Gleysols according to the non-parametric Kruskal-Wallis hypothesis test at 5\% probability. In general, soils are dystrophic, with low potential CEC, except for Fluvisols and Gleysols Ferralsols has clayic texture, whereas the Podzols, Planosols and Arenosols have a sandy-loam texture (Table 1). 
Table 1. Descriptive statistics (median \pm coefficient of variation \%) of topsoil properties for soils in Amazonas State and comparative data

\begin{tabular}{|c|c|c|c|c|c|c|c|}
\hline Soil group (n) & OC (\%) & $\mathrm{C}: \mathrm{N}$ & $\mathrm{N}(\%)$ & $\mathrm{CEC}\left(\mathrm{cmol}_{\mathrm{c}} \mathrm{dm}^{-3}\right)$ & Clay $(\%)$ & Silt (\%) & Sand (\%) \\
\hline ha AC ce 'a' (335) & $2.09 \pm 67$ & $9 \pm 55$ & $0.10 \pm 153$ & $10.1 \pm 62$ & $21 \pm 52$ & $28 \pm 66$ & $47 \pm 52$ \\
\hline ha AC ce 'b' (10) & $1.62 \pm 45$ & $10 \pm 41$ & $0.08 \pm 68$ & $15.1 \pm 34$ & $34 \pm 33$ & $42 \pm 36$ & $16 \pm 78$ \\
\hline ha AC ce 'c' (6) & $1.86 \pm 55$ & $23 \pm 31$ & $0.08 \pm 101$ & $7.1 \pm 55$ & $46 \pm 20$ & $9 \pm 89$ & $41 \pm 26$ \\
\hline ha AR dy (27) & $1.91 \pm 69$ & $6 \pm 72$ & $0.06 \pm 84$ & $5.3 \pm 78$ & $6 \pm 153$ & $16 \pm 87$ & $74 \pm 40$ \\
\hline ha CM (29) & $1.91 \pm 90$ & $7 \pm 46$ & $0.06 \pm 103$ & $10.0 \pm 56$ & $20 \pm 54$ & $36 \pm 61$ & $47 \pm 63$ \\
\hline eu FL ax sl (26) & $1.16 \pm 81$ & $5 \pm 67$ & $0.10 \pm 99$ & $10.2 \pm 42$ & $13 \pm 70$ & $43 \pm 57$ & $29 \pm 73$ \\
\hline ha FR ce 'a' (67) & $2.32 \pm 48$ & $10 \pm 34$ & $0.10 \pm 64$ & $9.5 \pm 39$ & $38 \pm 48$ & $11 \pm 96$ & $45 \pm 54$ \\
\hline ha FR ce 'b' (2) & $3.25 \pm 41$ & $10 \pm 41$ & $0.09 \pm 41$ & $11.0 \pm 41$ & $73 \pm 10$ & $11 \pm 38$ & $15 \pm 22$ \\
\hline ha FR ce 'c' (64) & $1.91 \pm 61$ & $23 \pm 24$ & $0.08 \pm 97$ & $10.1 \pm 54$ & $29 \pm 55$ & $17 \pm 60$ & $48 \pm 48$ \\
\hline fv eu GL sl (46) & $1.68 \pm 107$ & $5 \pm 58$ & $0.16 \pm 94$ & $18.2 \pm 63$ & $37 \pm 40$ & $48 \pm 37$ & $5 \pm 124$ \\
\hline ha PL dy (11) & $2.38 \pm 79$ & $15 \pm$ & $0.08 \pm 106$ & $5.9 \pm 56$ & $10 \pm 46$ & $34 \pm 42$ & $54 \pm 27$ \\
\hline ha PT dy (53) & $1.80 \pm 85$ & $8 \pm 48$ & $0.10 \pm 80$ & $10.1 \pm 68$ & $19 \pm 61$ & $37 \pm 63$ & $34 \pm 69$ \\
\hline al PZ jp (25) & $2.20 \pm 102$ & $12 \pm 62$ & $0.06 \pm 176$ & $5.0 \pm 151$ & $3 \pm 150$ & $10 \pm 110$ & $87 \pm 36$ \\
\hline All (701) & $2.03 \pm 75$ & $9 \pm 35$ & $0.09 \pm 136$ & $10.0 \pm 69$ & $26 \pm 65$ & $25 \pm 71$ & $45 \pm 59$ \\
\hline \multicolumn{8}{|l|}{ Data comparison } \\
\hline Indonesian rainforest soils ${ }^{3}(7)$ & $3.65 \pm 73$ & - & - & $12.76 \pm 69$ & $27 \pm 77$ & $39 \pm 45$ & $34 \pm 86$ \\
\hline Phillipine rainforest soils ${ }^{4}(4)$ & $3.31 \pm 23$ & - & - & $18.95 \pm 52$ & $50 \pm 37$ & $25 \pm 52$ & $25 \pm 27$ \\
\hline Atlantic tropical forest soils ${ }^{5}(4)$ & $9.6 \pm 45$ & $14 \pm 1$ & - & - & $20 \pm 57$ & $13 \pm 64$ & $67 \pm 22$ \\
\hline Brazilian savana soils ${ }^{6}(11)$ & $2.0 \pm 61$ & - & - & $55.4 \pm 52$ & $25 \pm 69$ & $4 \pm 6$ & $71 \pm 266$ \\
\hline Pantanal soils ${ }^{7}(150)$ & $2.30 \pm 47$ & - & - & $9.31 \pm 32$ & $13 \pm 24$ & $28 \pm 23$ & $59 \pm 14$ \\
\hline Xeric shrubland soils ${ }^{8}(12)$ & $2.20 \pm 48$ & - & - & \pm & $16 \pm 58$ & $14 \pm 67$ & $70 \pm 22$ \\
\hline
\end{tabular}

Note. $\mathrm{n}$ = sample number; $\mathrm{CEC}=$ cation Exchange capacity; $\mathrm{OC}=$ soil organic carbono content; Haplic 'Yellow' Acrisol clayic (ha AC ce 'a'); Haplic 'Red' Acrisol clayic ha AC ce 'b'; Haplic 'Red-Yellow' Acrisol clayic (ha AC ce 'c'); Haplic Arenosol dystric (ha AR dy); Haplic Cambisol (ha CM); Eutric Fluvisol Alcalic Siltic (eu FL ax sl); Fluvic Eutric Gleysol Siltic (fv eu GL sl); Haplic 'Yellow' Ferralsol clayic (ha FR ce 'a'); Haplic 'Red' Ferralsol clayic (ha FR ce 'b'); Haplic 'Red-Yellow' Ferralsol clayic (ha FR ce 'c'); Haplic Planosol dystric (ha PL dy); Haplic Plinthosol dystric (ha PT dy); Alic Podzol Hyperspodic (al PZ jp); 3 = (Anda, 2012); $4=$ (Navarrete et al., 2009); $5=$ (Martins, 2010, 2011); $6=($ Santos \& Alleoni, 2013); $7=($ Duarte, 2007$) ; 8=$ (Preston et al., 2014).

Organic carbon content was strongly and positively correlated with total N content, C:N ratio and CEC (Figure 2). The PC analysis showed that the first two principal components (PCs) accounted for $64 \%$ of the data variance (Figure 3). PCs with eigenvalues below 1.0 do not reflect the variability of data and provide little explanatory power beyond original variables, so they were excluded from the following interpretations. 

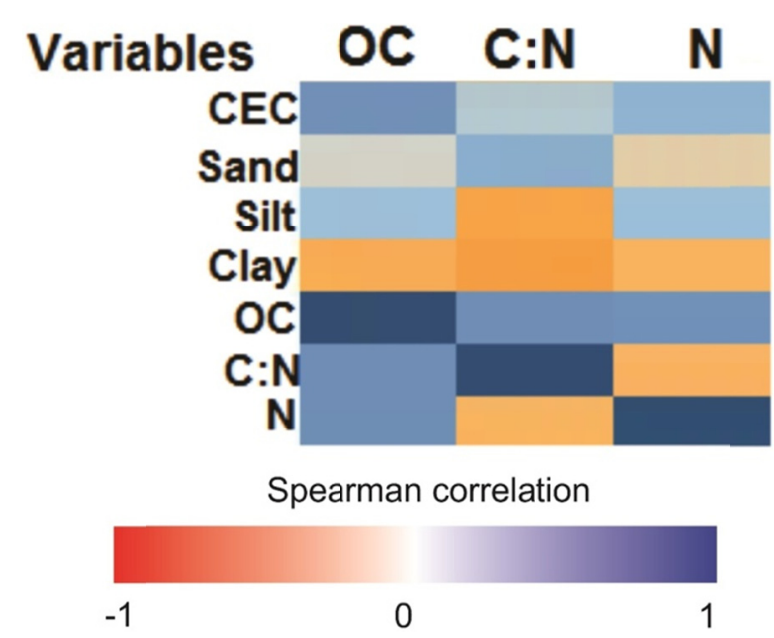

Figure 2. Correlation matrix of soil properties

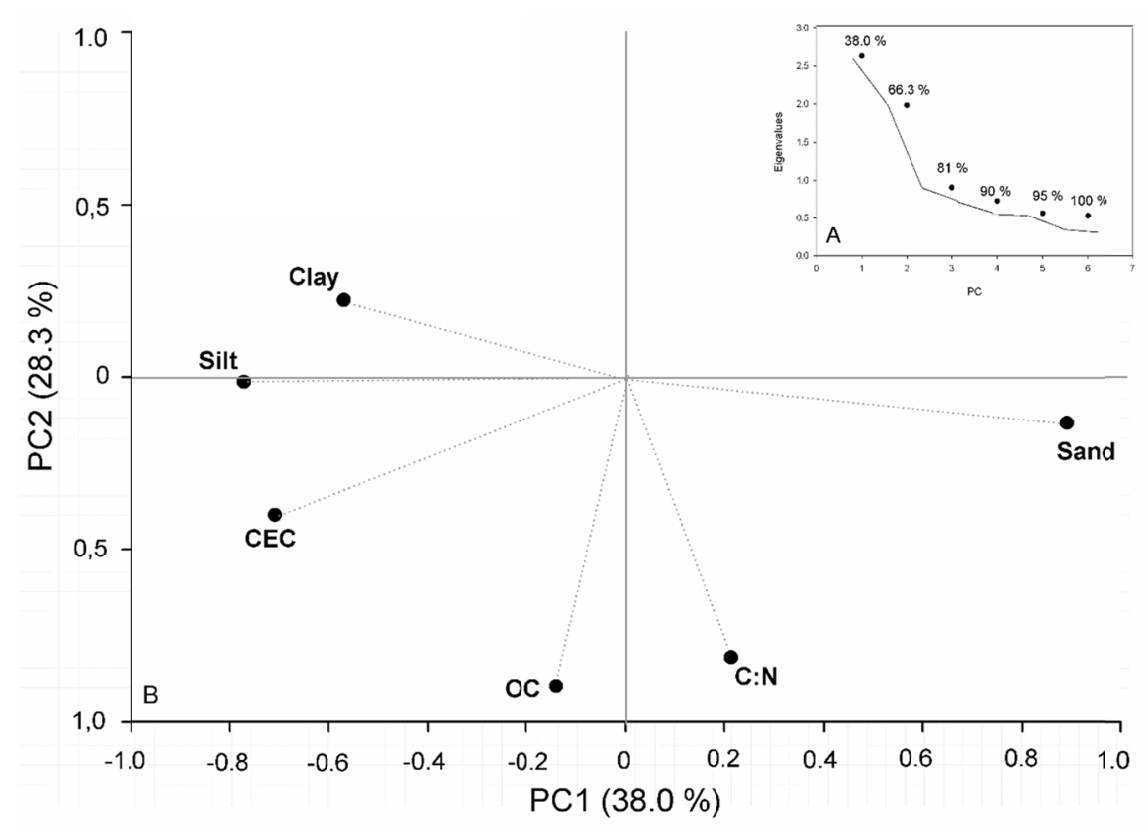

Figure 3. Eigenvalues of correlation and explained variance per PC (A). Projection of variables on the factor plane $\mathrm{PC} 1 \times \mathrm{PC} 2(\mathrm{~B})$

The first component ( $\mathrm{PC} 1$ ) explained $38 \%$ of the total variation of the data. Clay, silt and sand contents has the highest eigenvalues of PC1. The second component (PC2) explained $28 \%$ of the total variation and is strongly correlated with total organic carbon content and with the C:N ratio. PC1 can be associated with variability of source materials and pedogenetic processes, which combined, result in granulometric variation between soils. The low eigenvalues of organic carbon content and C:N ratio in relation to the CP1 indicate that the organic fraction of soils is not associated with soil texture. The strong relationship between OC values and C:N ratio in PCA is also evidenced with maps created from ordinary kriging (Figure 4). 




Figure 4. Ordinary kriging of C:N ratio (A) and OC content (B)

The spatial distribution of $\mathrm{OC}$ and $\mathrm{C}: \mathrm{N}$ ratio were influenced by parent material and other soil formation factors. High C:N ration values occur in soils derived from organic and clastic rocks in Solimões basin and clastic rocks in Tapajós basin. High OC values also occur in soils derived from rocks and sediments in Solimões Basin, although they presented a different spatial pattern. Besides that, OC values above $1.74 \%$ presented similar spatial distribution pattern to the dense rainforest distribution and a high spatial contiguity of contents.

\section{Discussion}

The high levels of OC in Ferralsols and Acrisols in Amazonas State confirm previous studies that indicate the importance of these soil groups in the global carbon stock (Lal, 2004; Fidalgo et al., 2007). Soils derived from crystalline rocks in Indonesia and Philippines has the highest organic carbon stock (Navarrete et al., 2009; Anda, 2012), as well in Amazonian rainforest.

Differences between spatial distribution of OC and C:N ratio and correlation of OC with CEC texture suggest various mechanisms of $\mathrm{C}$ stock in soil. Positive correlation between $\mathrm{OC}$ and $\mathrm{C}: \mathrm{N}$ ratio indicates that some of the highest organic carbon reserves in the Amazonian soils are maintained in fractions more resistant to decomposition (Figures 2 and 3). 
Positive correlation between OC and CEC and low correlation with texture in Amazonas can be attributed to distinct pedogenetic processes in the region. High correlation value between $\mathrm{OC}$ and $\mathrm{CEC}$ is attributed to the high specific surface of organic matter, which may be responsible for $50 \%$ to $90 \%$ of the CEC, mainly in clayey soils of clay fraction dominated by $\mathrm{Al} / \mathrm{Fe}$ (hydr)oxides and kaolinite (Silva \& Mendonça, 2007). High levels of OC in clayey and oxidic soils, such as Ferralsols, can be attributed to preservation of OC by complexes formed with mineral fraction of soil (Telles et al., 2003; Dalmolin et al., 2005). Humus is not readily decomposed in clayey soils because it is either physically protected inside soil aggregates or it is chemically too complex to be used by most organisms (Carter, 2000; Six et al., 2002; Šimanský \& Bajcan, 2014). On the other hand, the high OC contents in sandy soils, such as Podzols, can be associated with reducing conditions generally associated with the podzolization process, its position in landscape and its proximity to water table (IUSS Working Group WRB, 2014; Mendonça et al., 2014). Aerobic organisms can not act under low levels of $\mathrm{O}_{2}$, so that in environments with poor drainage only anaerobic organisms can decompose organic compounds. Under these conditions, decomposition of organic materials is lessened and incomplete. Consequently, the overall organic compounds decomposition rates are slower in flooded soils than those in aerobic soils and this results in net accumulation of organic carbon.

The highest OC levels were observed in Amazon rainforest soils, the Atlantic Forest and the tropical forests of Indonesia and Philippines. Similar OC contents between Amazonian and Atlantic rainforests and tropical forests in Indonesia and the Philippines suggest that the content is conditioned by the humid tropical climate. The OC level is controlled by supply of organic, C:N ratio and rate of decomposition (Puig, 2001; Ryan \& Law, 2005; Barros \& Fearnside, 2016).

The absence of a similar spatial pattern between distribution of phytophysiognomies and OC content indicates that, in tropical humid conditions with intense organic matter decomposition, differences in the amount of biomass produced by the different phytophysiognomies (Dense forest $=533.4 \mathrm{t} / \mathrm{ha}$; Open forest $=517.3 \mathrm{t} / \mathrm{ha}$; white-sand vegetation $=15.9 \mathrm{t} / \mathrm{ha}$ (Woortmann, 2010; IBGE, 2011) do not produce different soil organic carbon stock (Figure 4). On the other hand, high levels of organic matter in soils derived from Pleistocene organic sedimentary rocks of the Solimões Basin suggest that the OC content in Amazonas can be associated to parent material of soil. Soils derived from organic rocks have part of their soil organic carbon content attributed to parent material incorporated into the soil during pedogenesis (Rumpel et al., 2001a, 2001b).

In Brazil, it is estimated that organic $\mathrm{C}$ stocks in the soil under native vegetation, between 0 and $30 \mathrm{~cm}$ deep, total 36.4 Pg (Bernoux, 2002). The total organic carbon stock in the soil surface horizon in the Legal Amazon is $27.7 \times 100 \mathrm{t}$. The state of Amazonas is responsible for approximately $9.0 \times 100 \mathrm{t}$ of this organic carbon (IBGE, 2011). However, removal of vegetation on these soils favors the emission of greenhouse gases and the decrease of carbon stock (Dias, 2010; Lal et al., 2012; Nobre et al., 2016).

The last years are marked by an increase in the deforestation rate in the Amazonas State, especially in public lands not destined or without land information (IMAZON, 2014). Occupation of the Amazon rainforest has been concentrated on Ferralsols and Acrisols, soils with large carbon stocks and prone to the emission of the highest $\mathrm{CO}_{2}$ rates after deforestation (Bernoux et al., 2001; Dalmolin \& Caten, 2013; IBGE, 2015a). Forest conversion to agricultural ecosystems can result in the loss of $20-50 \%$ of soil carbon ( $\mathrm{Lal}, 2005)$. The proximity of the Ferralsols to the deforestation arc and the state capital, Manaus, causes concern due to possible changes in soil use and potential anthropogenic pressure.

\section{Conclusion}

The high variability of OC and clay contents in soils of the State of Amazonas was attributed to the diversity of the parent material and pedogenesis. It was verified that the Haplic 'Yellow' Ferralsols have the highest values of OC, followed by Haplic 'Yellow' Acrisols and Podzols, representing an area of more than 70\% of the state. The dominance of very weathered clayic soils or under strong influence of the water table contributes to the accumulation of OC. The highest values of OC and C:N ratio in the Solimões Basin are attributed to the presence of organic rocks. The results highlight the urgent need for appropriate polices for $\mathrm{C}$ stocks according to soil variability.

Amazon rainforest is responsible for storing large amounts of organic carbon in the soil due to its extension and preservation of the native forest. The state of Amazonas gains importance in this issue because it owns a large part of its territory with the preserved forest and is the largest state in Brazil. This study serves as a support for managers and environmental agencies in creation of priority areas for conservation of ecosystems and soil, as well as being the first step to map the areas with the highest levels of organic carbon in tropical forest soils. 


\section{References}

Aduan, E., Fatima, V., \& Klink, C. (2003). Ciclagem de Carbono em Ecossistemas Terrestres-O caso do Cerrado Brasileiro (1st ed., p. 28). Planaltina: Embrapa Cerrados. Retrieved from https://www.embrapa.br/ busca-de-publicacoes/-/publicacao/569012/ciclagem-de-carbono-em-ecossistemas-terrestres-o-caso-do-cerr ado-brasileiro

Anda, M. (2012). Cation imbalance and heavy metal content of seven Indonesian soils as affected by elemental compositions of parent rocks. Geoderma, 189-190, 388-396. https://doi.org/10.1016/j.geoderma.2012. 05.009

Asner, P., Powell, N., Mascaro, J., Knapp, D., Clark, K., Jacobson, J., ... Hughes, R. (2010). High-resolution forest carbon stocks and emissions in the Amazon. Proc Natl Acad Sci, 107, 16738-16742. https://doi.org/10.1073/pnas.1004875107

Barros, H., \& Fearnside, P. (2016). Soil carbon stock changes due to edge effects in central Amazon forest fragments. For Ecol Manage, 379, 30-36. https://doi.org/10.1016/j.foreco.2016.08.002

Batjes, N., \& Dijkshoorn, J. (1999). Carbon and nitrogen stocks in the soils of the Amazon Region. Geoderma, 89, 273-286. https://doi.org/10.1016/S0016-7061 (98)00086-X

Bernoux, M., Carvalho, M. C. S., Volkoff, B., \& Cerri, C. C. (2002). Brazil's soil carbon stocks. Soil Sci. Soc. Am. J., 66, 888-896. https://doi.org/10.2136/sssaj2002.8880

Bernoux, M., Conceição, M., Carvalho, S., \& Volkoff, B. (2001). CO2 emission from mineral soils following land-cover change Braazil. Glob Chang Biol, 7, 779-787. https://doi.org/10.1046/J.1354-1013.2001.00446.x

Campos, M., Ribeiro, M., Júnior, V., Filho, M., Souza, R., \& Almeida, M. (2011). Caracterização e classificação de terras pretas arqueológicas na região do médio rio madeira. Bragantia, 70, 598-608. https://doi.org/ $10.1590 / \mathrm{S} 0006-87052011000300016$

Carter, M. (2000). Organic Matter and Sustainability. In R. Rees, B. Ball, C. Campbell, \& C. Watson (Eds.), Sustain Manag Soil Org Matter (pp. 9-32). New York: CABI Publishing.

Dalmolin, R., \& Caten, A. (2013). Uso da terra dos biomas brasileiros e o impacto sobre a qualidade do solo. Entre-Lugar, 6, 181-193. Retrieved from http://ojs.ufgd.edu.br/index.php/entre-lugar/article/viewFile/ $2454 / 1405$

Dalmolin, R., Gonçalves, C., Dick, P., Knicker, H., Klamt, E., \& Kögel-Knabner, I. (2005). Organic matter characteristics and distribution in Ferralsol profiles of a climosequence in southern Brazil. Eur J Soil Sci, 57, 644-654. https://doi.org/10.1111/j.1365-2389.2005.00755.x

Demattê, J., \& Demattê, J. (1993).Comparações entre as propriedades químicas de solos das regiões da floresta amazônica e do cerrado do Brasil Central. Sci Agric, 50, 272-286. https://doi.org/10.1590/S0103-901 61993000200016

Dias, R. R. A. (2010). Modelagem dos estoques de carbono do solo sob diferentes coberturas na região do Cerrado (Universidade de Brasília, Brasília, Brazil).

DNPM (Departamento Nacional de Produção Mineral). (1975). Folha NA. 20 Boa Vista e parte das folhas NA. 21 Tuтиситаque, NB. 20 Roraima, NB. 21; geologia, geomorfologia, pedologia, vegetação, uso potencial da terra/Projeto RADAMBRASIL. Rio de Janeiro, Brazil.

DNPM (Departamento Nacional de Produção Mineral). (1976a) Folha NA. 19 Pico da Neblina; geologia, geomorfologia, pedologia, vegetação, uso potencial da terra/Projeto RADAMBRASIL. Rio de Janeiro, Brazil.

DNPM (Departamento Nacional de Produção Mineral). (1976b). Folha SA. 21 Santarém; geologia, geomorfologia, pedologia, vegetação, uso potencial da terra/Projeto RADAMBRASIL. Rio de Janeiro, Brazil.

DNPM (Departamento Nacional de Produção Mineral). (1976c). Folha SC. 19 Rio Branco; geologia, geomorfologia, pedologia, vegetação, uso potencial da terra/Projeto RADAMBRASIL. Rio de Janeiro, Brazil.

DNPM (Departamento Nacional de Produção Mineral). (1977a). Folha SA. 19 Içá; geologia, geomorfologia, pedologia, vegetação, uso potencial da terra/Projeto RADAMBRASIL. Rio de Janeiro, Brazil.

DNPM (Departamento Nacional de Produção Mineral). (1977b). Folha SB. 19 Juruá; geologia, geomorfologia, 
pedologia, vegetação, uso potencial da terra/Projeto RADAMBRASIL. Rio de Janeiro, Brazil.

DNPM (Departamento Nacional de Produção Mineral). (1977c). Folha SB/SC. 18 Javai/Contamona; geologia, geomorfologia, pedologia, vegetação, uso potencial da terra/Projeto RADAMBRASIL. Rio de Janeiro, Brazil.

DNPM (Departamento Nacional de Produção Mineral). (1978a). Folha SA. 20 Manaus; geologia, geomorfologia, pedologia, vegetação, uso potencial da terra/Projeto RADAMBRASIL. Rio de Janeiro, Brazil.

DNPM (Departamento Nacional de Produção Mineral). (1978b). Folha SB. 20 Purus; geologia, geomorfologia, pedologia, vegetação, uso potencial da terra/Projeto RADAMBRASIL. Rio de Janeiro, Brazil.

DNPM (Departamento Nacional de Produção Mineral). (1978c). Folha SC.20 Porto Velho; geologia, geomorfologia, pedologia, vegetação, uso potencial da terra/Projeto RADAMBRASIL. Rio de Janeiro, Brazil.

DNPM (Departamento Nacional de Produção Mineral). (1980). Folha SC. 21 Jurena; geologia, geomorfologia, pedologia, vegetação, uso potencial da terra/Projeto RADAMBRASIL. Rio de Janeiro, Brazil.

Donagema, G. K., Campos, D. V. B de, Calderano, S. B., Teixeira, W. G., \& Viana, J. H. M. (2011). Manual de métodos de análise de solos (2nd ed., p. 230). Rio de Janeiro: Embrapa Solos.

Duarte, T. G. (2010). Florística, fitossociologia e relações solo-vegetação em floresta estacional decidua em Barão de Melgaço, Pantanal de Mato Grosso (Universidade Federal de Viçosa, Viçosa, Brazil).

Fearnside, P. M. (2018). Brazil's Amazonian forest carbon: The key to Southern Amazonia's significance for global climate. Reg Environ Chang, 18, 47-61. https://doi.org/10.1007/s10113-016-1007-2

Fidalgo, E. C. C. (2007). Estoques de carbono nos solos do Brasil (1st ed., p. 27). Rio de Janeiro: Embrapa Solos.

Guimarães, S. T., Lima, H. N., Teixeira, W. G., Neves, A. F., Silva, F, W. R., Macedo, R. S., \& Souza, K. W. (2013). Caracterização e classificação de Gleissolos da várzea do rio Solimões (Manacapuru e Iranduba), Amazonas, Brasil. Rev Bras Cienc do Solo, 37, 317-326. https://doi.org/10.1590/S0100-06832013000 200003

Hoorn, C., Wesselingh, F. P., Ter Steege, H., Bermudez, M. A., Mora, A., Sevink, J., ... Antonelli, A. (2010). Amazonia Through Time: Andean Uplift, Climate Change, Landscape Evolution, and Biodiversity. Science, 330, 927-931. https://doi.org/10.1126/science.1194585

Houghton, R. A., Hall, F., \& Goetz, S. J. (2009). Importance of biomass in the global carbon cycle. J Geophys Res Biogeosciences, 114, 1-13. https://doi.org/10.1029/2009JG000935

Houghton, R., Lawrence, K. T., Hackler, J. L., \& Brown, S. (2001). The spatial distribution of forest biomass in the Brazilian Amazon: A comparison of estimates. Glob Chang Biol, 7, 731-746. https://doi.org/10.1111/ j.1365-2486.2001.00426.x

IBGE (Instituto Brasileiro de Geografia e Estatística). (2010). Mapa de Vegetação do Estado do Amazonas. Retrieved from http://www.mma.gov.br/biomas/amaz\%C3\%B4nia/mapa-de-cobertura-vegetal

IBGE (Instituto Brasileiro de Geografia e Estatística). (2011). Geoestatísticas de Recursos Naturais da Amazônia Legal em 2003. Rio de Janeiro: Brazil. Retrieved from https://biblioteca.ibge.gov.br/index.php/ biblioteca-catalogo? view $=$ detalhes $\&$ id $=249694$

IBGE (Instituto Brasileiro de Geografia e Estatística). (2015a). Levantamento Sistemático da Produção Agrícola (LSPA). Rio de Janeiro: Brazil. Retrieved from https://www.ibge.gov.br/estatisticas-novoportal/economicas/ agricultura-e-pecuaria/9201-levantamento-sistematico-da-producao-agricola.html

IBGE (Instituto Brasileiro de Geografia e Estatística). (2015b). Mudanças da Cobertura e do uso da tera. Rio de Janeiro: Brazil. Retrieved from ftp://geoftp.ibge.gov.br/informacoes_ambientais/cobertura_e_uso_da_terra/ mudancas/documentos/mudancas_de_cobertura_e_uso_da_terra_2000_2010_2012_2014.pdf

IBM. (2016). Tutorial of IBM SPSS Statistics 24. Retrieved from http://www-01.ibm.com/support/docview.wss? uid $=$ swg24041224

IMAZON (Instituto do Homem e do Meio Ambiente da Amazônia). (2014). O aumento no Desmatamento na Amazônia em 2013: Um ponto fora da curva ou fora de controle? Brasília, Brazil. Retrivied from http://imazon.org.br/PDFimazon/Portugues/outros/Aumento\%20no\%20Desmatamento\%20na\%20Amazoni a\%20em\%202013.pdf 
IUSS Working Group WRB. (2014). World reference base for soil resources 2014. International Soil Classification System for Naming Soils and Creating Legends for Soil Maps. Retrieved from http://www.fao.org/soils-portal/soil-survey/soil-classification/world-reference-base/en

Jobbágy, E. G., \& Jackson, R. B. (2000). The vertical distribution of soil organic carbon and its relation to climate and vegetation. Ecol Appl, 10, 423-436. https://doi.org/10.1890/1051-0761(2000)010[0423:TVDO $\mathrm{SO}] 2.0 . \mathrm{CO} ; 2$

Koele, N., Bird, M., Haig, J., Marimon-Junior, B. H., Marimon, B. S., Phillips, O. L., ... Feldpausch, T. R. (2017). Amazon Basin forest pyrogenic carbon stocks: First estimate of deep storage. Geoderma, 306, 237-243. https://doi.org/10.1016/j.geoderma.2017.07.029

Lal, R. (2004). Soil carbon sequestration impacts on global climate change and food security. Science, 304, 1623-7. https://doi.org/10.1026/science.1097396

Lal, R. (2005). Forest soils and carbon sequestration. For Ecol Manage, 220, 242-258. https://doi.org/10.1016/ j.forece.2005.08.015

Lal, R., Lorenz, K., \& Schneider, R. F. U. B. (2012). Recarbonization of the Biosphere (1st, p. 560). Netherlands: Springer. https://doi.org/10.1007/978-94-007-4159-1

Lima, H. N., Mello, J. W. V., Schaefer, C. E. G. R., \& Ker, J. C. (2005). Dinâmica da mobilização de elementos em solos da Amazônia submetidos à inundação. Acta Amaz, 35, 317-330. https://doi.org/10.1590/ S0044-59672005000300003

Maia, M., \& Marmos, J. (2010). Geodiversidade do Estado do Amazonas (1st, p. 21). Manaus-AM: CPRM. Retrieved from http://rigeo.cprm.gov.br/jspui/handle/doc/16624

Marengo, J. A., \& Nobre, C. A. (2009). Clima da Região Amazônica. In I. F. A. C. Cavalcanti, N. J. Ferreira, M. G. A. J. Silva, \& M. A. F. S. Dias (Eds.), Tempo e clima no Brasil (pp. 197-214). São Paulo: Oficina de Textos.

Marques, J. J., Teixeira, W. G., Schulze, D. G., \& Curi, N. (2002). Mineralogy of soils with unusually high exchangeable Al from the western Amazon Region. Clay Miner, 37, 651-661. https://doi.org/10.1180/ 0009855023740067

Martins, B. L. F. (2010). Alterações nos fluxos de gases do solo e na ciclagem de carbono e nitrogênio após aquecimento do solo em áreas de Mata Atlântica (Escola Superior de Agricultura Luiz de Queiroz, Piracicaba, Brazil).

Martins, S. C. (2010). Caracterização dos solos e serrapilheira ao longo do gradiente altitudinal da Mata Atlântica, estado de São Paulo (Universidade de São Paulo, São Paulo, Brazil).

McKillup, S., \& Dyar, M. D. (2010). Geostatistics Explained: An Introductory Guide for Earth Scientists (1st, p. 414). Cambridge: Cambridge University Press. https://doi.org/10.1017/CBO9780511807558

Mendonça, B. A. F., Simas, F. N. B., Schaefer, C. E. G. R., Filho, E. I., Vale Júnior, J. F., \& Mendonça, J. G. F. (2014). Podzolized soils and paleoenvironmental implications of white-sand vegetation (Campinarana) in the Viruá National Park, Brazil. Geoderma Reg, 2-3, 9-20. https://doi.org/10.1016/j.geodrs.2014.09.004

Mendonça, B., Fernandes, E., Schaefer, C., Mendonça, J., \& Vasconcelos, B. (2017). Soil-vegetation relationships and community structure in a "terra-firme"-whitesand vegetation gradient in Viruá National Park, Northern Amazon, Brazil. An Acad Bras Cienc, 89, 1269-1293. https://doi.org/10.1590/0001-3765 201420160666

Navarrete, I., Tsutsuki, K., Asio, V. B., \& Kondo, R. (2009). Characteristics and formation of rain forest soils derived from late Quaternary basaltic rocks in Leyte, Philippines. Environ Geol, 58, 1257-1268. https://doi.org/10.1007/s00254-008-1627-z

Nobre, C. A., Sampaio, G., Borma, L. S., Castilla-Rubio, J. C., Silva, J. S., \& Cardoso, M. (2016). Land-use and climate change risks in the Amazon and the need of a novel sustainable development paradigm. Proc Natl Acad Sci., 113, 10759-10768. https://doi.org/10.1073/pnas.1605516113

Nogueira, E. M., Yanai, A. M., Fonseca, F. O. R., \& Fearnside, P. M. (2015). Carbon stock loss from deforestation through 2013 in Brazilian Amazonia. Glob Chang Biol, 21, 1271-1292. https://doi.org/ 10.1111/gcb.1279

Preston, W., Nascimento, C. W. A., Biondi, C. M., Souza Junior, V. S., Da Silva, W. R., \& Ferreira, H. A. (2014). 
Valores de referência de qualidade para metais pesados em solos do Rio Grande do Norte. Rev Bras Cienc do Solo, 38, 1028-1037. https://doi.org/10.1590/S0100-06832014000300035

Puig, H. (2001). La forêt tropicale humide (1st, p. 448). Paris: Belin.

Reis, N., Almeida, M., Riker, S., \& Ferreira, A. (2006). Geologia e recursos minerais do Estado do Amazonas (1st ed., p. 156). Manaus: CPRM.

Rosenberg, M. S., \& Anderson, C. D. (2011). PASSaGE : Pattern Analysis, Spatial Statistics and Geographic Exegesis. Methods Ecol Evol, 2, 229-232. https://doi.org/10.1111/j.2041-210X.2010.0008.x

Rumpel, C., Grootes, P, M., \& Knabner, I. K. (2001a). Quantification of carbon derived from lignite in soils using mid-infrared spectroscopy and partial least squares. Organic Geochemistry, 32, 831-839. https://doi.org/10.1016/S0146-6380(01)00029-8

Rumpel, C., Janik, J. L. J. O., \& Knabner, I. K. (2001b). Characterisation of the microbial biomass in lignite-containing mine soils by radiocarbon measurements. Soil Biol Biochem, 33, 2019-2021. https://doi.org/10.1016.S0038-0717(01)00122-5

Ryan, M. G., \& Law, B. E. (2005). Interpreting, measuring, and modeling soil respiration. Biogeochemistry, 73, 3-27. https://doi.org/10.1007/s10533-004-5167-7

Santos, H. G. S., Jacomine, P. K., Anjos, L. H. C., Oliveira, V. A., Lumbreras, J. F., Coelho, M. R., ... Oliveira, J. B. (2013). Sistema brasileiro de classificação de solos (3rd ed., p. 351). Rio Janeiro: Embrapa Solos.

Santos, S. N., \& Alleoni, L. R. F. (2013). Reference values for heavy metals in soils of the Brazilian agricultural frontier in Southwestern Amazônia. Environ Monit Assess, 185, 5737-48. https://doi.org/10.1007/ s10661-012-2980-7

Silva, I., \& Mendonça, E. S. (2007). VI- Matéria orgânica do solo. In R. F. Novais (Eds.), Fertildade do Solo (p. 1017). Viçosa: Sociedade Brasileira de Ciência do Solo.

Šimanský, V., \& Bajcan, D. (2014). Water stability of soil aggregates and their ability to sequester carbon in soils of vineyards in Slovakia. Soil Water Res., 9, 111-118. https://doi.org/10.1080/03650340.2015.1048683

Six, J., Conant, R. T., Paul, E. A., \& Paustian, K. (2002). Stabilization mechanisms of soil organic matter: Implications for C-saturatin of soils. Plant Soil, 241, 155-176. https://doi.org/10.1023/A:1016125726789

Soares, T. de J., \& Higuchi, N. (2006). A convenção do clima e a legislação brasileira pertinente, com ênfase para a legislação ambiental no Amazonas. Acta Amaz, 36, 573-580. https://doi.org/10.1590/S0044-5967 2006000400021

Souza, J., Fontes, M., Gilkes, R., Costa, L., \& Oliveira, T. (2018). Geochemical Signature of Amazon Tropical Rainforest Soils. Rev Bras Ciência do Solo, 42, 1-18. https://doi.org/10.1590/18069657rbcs20170192

Telles, E. C., Camargo, B. de P., Martinelli, L. A., Trumbore, S. E., Salazar, da C. E., Santos, J., ... Oliveira, Jr. R. (2003). Influence of soil texture on carbon dynamics and storage potential in tropical forest soils of Amazonia. Global Biogeochem Cycles, 17, 1-12. https://doi.org/10.1029/2002GB001953

Wackernagel, H. (2003). Multivariate Geostatistics: An Introduction with Applications (3rd ed., p. 388). New York: Verlag Berlin Heidelberg. https://doi.org/10.1007/978-3-662-05294-5

Woortmann, B. C. P. I. (2010). Equações alométricas, estoque de biomassa e teores de carbono e nitrogênio de campinaranas da Amazônia central (Institudo Nacional de Pesquisas da Amazônia, Manaus, Brazil).

Xavier, B. T. L. (2013). Mineralogia e teores naturais de metais pesados em solos da bacia sedimentar Amazônica (Universidade Federal de Viçosa, Viçosa, Brazil).

\section{Copyrights}

Copyright for this article is retained by the author (s), with first publication rights granted to the journal.

This is an open-access article distributed under the terms and conditions of the Creative Commons Attribution license (http://creativecommons.org/licenses/by/4.0/). 